
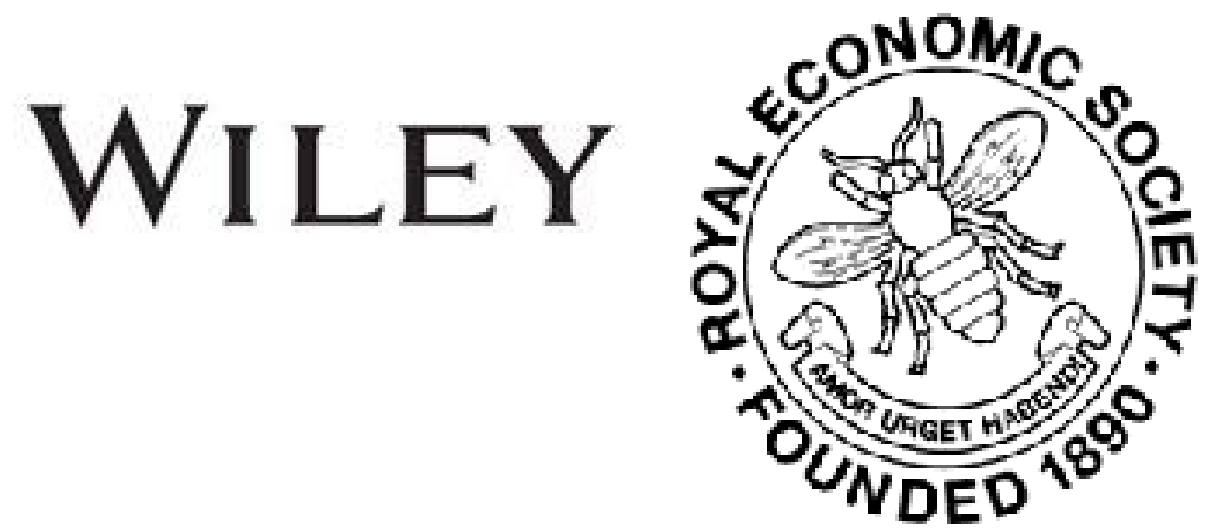

\title{
The Present Position of Irish Land Purchase
}

Author(s): C. F. Bastable

Source: The Economic Journal, Vol. 15, No. 60 (Dec., 1905), pp. 521-526

Published by: Wiley on behalf of the Royal Economic Society

Stable URL: http://www.jstor.org/stable/2221173

Accessed: 25-06-2016 17:00 UTC

Your use of the JSTOR archive indicates your acceptance of the Terms \& Conditions of Use, available at

http://about.jstor.org/terms

JSTOR is a not-for-profit service that helps scholars, researchers, and students discover, use, and build upon a wide range of content in a trusted digital archive. We use information technology and tools to increase productivity and facilitate new forms of scholarship. For more information about JSTOR, please contact support@jstor.org.

Wiley, Royal Economic Society are collaborating with JSTOR to digitize, preserve and extend access to The Economic Journal 


\section{THE PRESENT POSITION OF IRISH LAND PURCHASE.}

THE surprise so generally expressed at the difficulties which have beset the first years of the working of the "Wyndham" Act of 1903 has very little to justify it. The course of operations under this measure is not at all unlike what has happened in the case of earlier Land Acts. Immediately on the passing of the Act a rush of eager buyers and sellers appeared. Land agents advertised their readiness to negotiate sales, and in a few months more agreements were arranged than for twice as many years under the former Acts. The necessary consequence was a decided congestion, leading to a practical stopping of further transactions. But nearly everybody appears to have forgotten that a similar state of things followed the second Gladstone Act. That measure came into force on August 22nd, 1881, and the applications to fix fair rents soon rose to many thousands-far more than the Land Commission could itself deal with. To meet the difficulty, the Land League advised that only a few test cases should be presented, and that thus a standard of fair rent should be obtained, which would be available for general application. Unfortunately, this advice led to the imprisonment of the leaders of the association by the Liberal administration, with the result that the crush on the land court continued to such an extent that the responsible task of rent-fixing had perforce to be delegated to a number of subordinate, but practically independent, tribunals, with results that can hardly be regarded as satisfactory.

Events have repeated themselves in the case of the latest measure, but owing to the voluntary character of the transactions for purchase, the consequences have not proved so serious. It is, however, beyond doubt that the belief of the Government that not more than $£ 5,000,000$ worth of property per annum would be arranged for sale showed a remarkable ignorance of the real facts of the situation. According to the Report of the Estates Commissioners, the applications for the period November 1st, 
1903, to March 31st, 1905, amounted to $£ 20,145,320$-i.e., at the rate of nearly $14 \frac{1}{4}$ millions sterling per annum, or nearly three times the figure of the official estimate.

One obvious outcome of such miscalculations is the disappointment of expectations that have been reasonably excited by the measures that are thus curtailed in their action. A great deal of the difficulty that hampered the earlier years of the administration of the Act of 1881 was due to the confused notions as to the true standard of the judicial rents, which would have been adequately determined by considered judgments of the Chief Commissioners in a limited number of selected cases. Similar confusion, but, happily, not so disastrous in its general effects, is likely to follow the block in the land purchase system, due to an insufficient staff and inadequate funds.

Another parallel between the Act of 1881 and that of 1903 is furnished by the legal puzzles that imperfect drafting and haste in legislation have produced. Some of the most fundamental questions have been really left to the ingenuity of the judges to solve, and their solutions, it may be said, have not always been in accordance with the aim of the legislature or the economic needs of the community. The questions of tenants' improvements, of the fixing of true value for the purpose of pre-emption, and the right of resumption by the landlord, are instances in connection with the second Gladstone Act. The allocation of the bonus, the proper application of the term "estate," and the power of the Commissioners to buy untenanted land are cases that have arisen in the short time that the Act of 1903 has been in force. Thus there is nothing very exceptional or abnormal in the actual situation as compared with former times.

But the fact that legislation for Ireland is, as a rule, marked by undue haste and by the desire to overcome the diverse forms of opposition by employing ambiguous or unmeaning language, does not lessen the loss to the interests that are thereby affected. Legal expense and administrative delay are grievances that landlords and tenants both feel. They are also obstructions to agricultural progress. There is, however, another obstacle peculiar to the Wyndham Act. The greater part of the remedial legislation for Ireland has been carried out at Ireland's expense, or, at all events, without any serious call on the funds or the credit of the Imperial Government. Cliffe-Leslie once likened the English policy towards Ireland to that of Henry II. when he flung to a shivering beggar a cloak from the back of one of his own friends, and for the most part the gibe has been justified. The policy of 
land purchase has by degrees led to a more liberal attitude. Under the first purchase measures the public advances were amply protected : the Act of 1903 provides for loans where loss is possible, and even for cases in which it is certain, and it has also established a direct imperial contribution which will ultimately reach $£ 12,000,000$. There are, indeed, complicated arrangements for the use of Irish funds (so called) which, when analysed, amount to transfers from grants made for other purposes. It is almost certain that the political situation will lead to the placing of the several items of loss on the Consolidated Fund, and to the relief of the special sources that the ingenuity of the Treasury has devised. A fundamental point in the policy of land purchase, and one essential for its success, is its financing by the aid of imperial resources.

Since the initiation of the policy by the Ashbourne Act of 1885 down to the close of the century, the financial conditions were continuously favourable. The certainty of being able to borrow any requisite amount at a rate under 3 per cent. would have made operations far more extensive than those which were attempted quite easy. No doubt was felt on this point. It was often declared that landlords were unwilling to sell; inducements were tried to encourage hesitating tenants to buy ; but it was regarded on all sides as a law of nature that sufficient funds for purchase would be always forthcoming at a low rate of interest. How ill-founded this naïve belief was is now abundantly manifest. Instead of a market prepared to take any amount of land stock at 23 per cent., and even ready to pay a considerable premium for it, there is now a sensitive condition of the market which only allows of limited amounts of this very stock being placed at a discount of 10 per cent.

The causes of this change are evidently the effect of the South African War on State credit and the general strain on the money markets of the world by the greater Eastern conflict, supplemented by the absence of any real effort to re-establish an effective policy of debt redemption. An important imperial interest (for the present tranquillity of Ireland may be so regarded) is endangered through a failure in the observance of the rules of sound finance. Reduced expenditure (particularly in the form of loans) and creation of a true surplus would soon bring the Irish land stock to par and remove any fear of loss on its issue.

But failing this radical cure, there are expedients which may, it is thought, alleviate the difficulties of the situation. One of the commonest suggestions is the proposal to issue Treasury bills or 
notes, or credit instruments of some kind, which would circulate at a low interest, or, as some people hope, without interest. The mere statement of such plans suffices for their condemnation. Their authors have to learn the elements of finance (using the term in its vague and popular sense); but the desire of immediate advantage explains the advocacy of schemes of this kind by landlords eager to sell without delay at high prices.

A more feasible plan is that proposed by the present Irish Secretary, viz., the payment of the selling landlords in stock instead of in cash for one-half of the amount. This would be a partial return to the earlier system, which the landlord interest carried against the Government in the Act of 1896 in order to get the advantage of the premium that then existed on the stock. This would now mean a deduction of 5 per cent. from the purchase money received by the landlord, and has, therefore, naturally been unpalatable to the sellers of land. It may be added that it is open to the further disadvantage of supplying a basis for the claim that the system of part payment in stock should be continued when stock reached par or attained a premium. It would be plausibly argued that, as the landlord had lost by taking depreciated stock, so he would be entitled to gain from every rise in its value. But the most serious objection is the confusion between the two methods of payment, (1) in cash, (2) in stock. Either may be adopted, the former having much more to recommend it-the mixture of the two can only produce confusion and uncertainty, as well as dissatisfaction. For want of anything better, it is quite possible that Mr. Long's plan will be adopted for a limited time.

Another mode of dealing with the problem is the raising of the rate of interest on the land stock to 3 per cent. If a guarantee against redemption were given for a sufficient number of years (the existing 23 per cent. is irredeemable till 1933), the price would go to par, and the annuity payable by the tenant would have to be increased or the time of payment prolonged. This method has the disadvantage of establishing a 3 per cent. stock beside the two existing land stocks, but it must be remembered that the term of the stock need not be a long one, and that it would be consolidated with the earlier $2 \frac{3}{4}$ per cent. stock of 1903-5. More important is the consideration that the price received by the seller would almost certainly be reduced. At the beginning of the sales under the Wyndham Act, it was explained by the advocates of the landlords that the amount of the tenant's yearly payment (his purchase annuity) was his sole consideration-the payment to 
the landlord was a matter for the State. This contention is conclusive in favour of a reduction of the selling price equivalent to the smaller capital obtainable when interest is at 3 per cent. (or, including the sinking fund, at $3 \frac{1}{2}$ per cent.). The loss, however, would not be great, and the needier sellers would be practically forced to accept it in order to secure the favourable conditions of investment and to discharge their liabilities which carry 5 per cent. or 6 per cent. Those owners who are anxious to get rid of the troubles and uncertainty attending their purchase would also accept the position, and these are the classes that have furnished the supply that has glutted the land market created by the Act.

Another plan propounded has been the issue of certificates to owners who have sold, testifying that they will in the future (i.e. when sufficient funds are procurable) be entitled to the amount mentioned in the document. These instruments, it is thought, would be available for raising funds which would pay off charges that fall on the landowners. The further arrangement that the general system under which the tenant pays interest (usually $3 \frac{1}{2}$ per cent.) to his former landlord until the purchase money is paid out should be recognised in the certificates would practically make them a kind of interest-bearing security.

This scheme has the double disadvantage of being complicated and unlikely to attain its object; for the punctual payment of interest by the tenant could not be guaranteed in the case of each individual landlord, which would depreciate the value of the certificates as a whole, and the risk with attendant expenses would fall on the landowners who were compelled to resort to the credit agencies that would deal in these instruments.

On the whole the increase in the rate of interest on land stock is the least objectionable of the palliatives suggested. It recognises the facts of the situation, and if the tenants are anxious to escape from the payment of interest during the existing interval of waiting, there might not be an equivalent reduction in the landlord's purchase money.

Two or three general points remain for notice. First, the necessity of preventing the issue of stock at a discount which imposes a charge on Irish funds. The transactions between owners and tenants should, so far as Ireland is concerned, be made self-supporting. If imperial policy admits of a gift from the State (in addition to the bonus), it will be readily accepted. Second, the immense importance of maintaining the national credit is evident. Sound finance is the basis of sound policy. 
The situation in Ireland would have been perfectly simple and easy under the financial conditions of ten years ago. The real interdependence of English and Irish interests receives an effective illustration from the present situation of the land purchase question, and a curious light is thrown on the ignorance of the most important classes of society as to the policy most conducive to their true interests.

But perhaps the most serious matter is the difficulty that seems likely to beset land purchase in the future. The encumbered and absentee landlords are ready to part with their property, and so is the ordinary landlord so long as investment which will not lower his income is open to him. When, as may be hoped it will, the money market reverts to the conditions of the closing years of last century, it will be impossible for the encumbered owner to secure this result. Land purchase will then cease, and unless there has been some extraordinary change the demand for compulsory purchase will make its reappearance. This will, I believe, prove to be the Irish land problem of ten or fifteen years hence.

C. F. BAstablb 